\title{
The religion in higher education curriculum referring to Indonesian qualification framework: The inclusion of neuroscience and anti-corruption education
}

\author{
Suyadi $^{\mathrm{a}, 1, *(\mathbb{D})}$, Zalik Nuryana ${ }^{\mathrm{a}, 2}$ (D) Sutrisno $^{\mathrm{b}, 3}$ (D) \\ ${ }^{a}$ Faculty of Islamic Studies, Universitas Ahmad Dahlan, Indonesia \\ ${ }^{\text {b }}$ Universitas Islam Negeri Sunan Kalijaga, Indonesia \\ ${ }^{1}$ suyadi@fai.uad.ac.id*; ${ }^{2}$ zalik.nuryana@pai.uad.ac.id; ${ }^{3}$ trisno_63@yahoo.com \\ * corresponding author
}

ARTICLE INFO

Received 2020-04-09

Revised 2020-04-26

Accepted 2021-04-23

Published 2021-04-28

Keywords

Development of curriculum matrix

Islamic education

Higher education

Neuroscience of Islamic education

Anti-corruption education

\begin{abstract}
The research aims to develop the curriculum of the Higher Education Curriculum, specifically Islamic religion, referring to the Indonesian National Qualification Framework (KKNI). The problem raised in this research is the redesign of the curriculum in Indonesia, especially the formation of new courses such as the neuroscience of Islamic education and anti-corruption education, which have not considered the breadth of study material and calculation semester credit units that are not accountable. This research was conducted in three stages: curriculum analysis, curriculum matrix design, and curriculum matrix experimentation. The research subjects involved 133 lecturers in the Higher Education Institutions of Religion, both Islamic, Catholic, and Hindu in Indonesia. The findings indicate that the developed matrix design can be used as an integrative tool for forming subjects and calculating semester credit unit weights in a mathematical and accountable manner, and accommodating the development of Islamic education, particularly neuroscience and anti-corruption education. This matrix can complement Kim's research on syllabus ontology identification and lesson study innovation developed by E. Purwaningsih and D. Nurhadi.
\end{abstract}

This is an open access article under the CC-BY-SA license.

\section{Introduction}

Since the Presidential Regulation of the Republic of Indonesia Number 08/2012 concerning the Indonesia Qualification Framework (IQF) was released, each study program in all higher educations must redesign its curriculums regarding IQF [1]. In terms of forming a course, it must be conducted accountably by developing a matrix that connects learning outcomes with study material. Furthermore, the calculation of the unit weight of semester credit for each subject must also be done mathematically. This redesign must remain respondent to current issues in the scientific fields considering national priority, such as progressing Islamic education [2], neurosciences [3], and anticorruptive education [4]. This research is therefore different as it adds value to both previous studies. Hence, it can be integrated into the relevant sciences. However, most religion colleges in Indonesia have not implored using a matrix, which links learning outcomes and study material. Therefore, they are not accountable during calculating the semester credit unit weight as this is not done mathematically. Furthermore, the current religious higher education curriculum in Indonesia can only produce a list of courses, while the weighting of semester units but cannot be justified academically.

Research by Seaton stated that the phenomena, especially the most fundamental curriculum redesign, are learning proliferation [5]. Khan and Law noted that this is to isolate various educational 
elements, such as institutional leadership, social trends, industrial factors, and the role of government [6]. In Indonesia, inhibitive factors are widely determined by the seniority and authority of lecturers in the study program. Conversely, the formation of a course is merely based on the desire of senior lecturers, and credit calculation is solely estimated by the concerned lecturers. Studies concerning integrative curriculum development are widely done in medical faculties [7]. These have, however, not been conducted in religious higher education. However, an integrated curriculum in medicine widely focuses on integrating sciences and not on its matrix. Kim's study led to matrix development, where the syllabus for courses was designed [8], including study lessons [9]. This research is different, complementing Kim's research, which involves developing a matrix that can integrate study material in the syllabus between one subject and another, hence, they can be integrated scientifically.

This study offers a redesigned religious higher education curriculum model based on the problems described, which covers three aspects. First, the development of the curriculum redesign matrix connects the formulation of learning outcomes with study material. Secondly, the mathematical and accountable calculation of semester credit unit weight. Thirdly, it responds to the latest issues in scientific study programs, considering the national priority scale, especially in neuroscience and anticorruption education. Indonesian Qualification Framework (IQF) is a stratification system of competency qualification, juxtaposing, equalizing, and integrating education, training, and experience to give proficiency acknowledgments according to the occupational structure in various sectors [1]. Islamic higher education in the millennial or industrial era 4.0 [10] is one formulated in IQF. So far, religious higher education curriculum is one sector that must refer to the IQF since the competency qualifications of its graduates in Indonesia have not been systematized with the formulation in the IQF. To attain this, therefore, it is appropriate to redesign its curriculum, including, Islam, Catholicism and Hinduism.

Higher education curriculums are a set of plans and rules concerned with the learning achievements of alumni and their study materials, process, and assessment, which is used as a guide to implementing a study program [11]. However, in Indonesia, they are simply listing of courses without a trace of their origin. Furthermore, they have no logic in calculating credit as similar courses in a university has different credit weights. Since each study program in a university has various courses and credits, a mechanism to form courses and calculate credit weight is needed accountably. Redesign of religious higher education curriculum must be synced with other applicable regulations, especially when responding to current issues in the scientific field with inter-multi- and trans-disciplinary approaches. In this case, policy regulations relevant to IQF are anti-corruption education [12] courses at all levels of education [13].

One of the latest issues with the progression in science is neuroscience [14], [15], which has experienced the fastest development in the $21^{\text {st }}$ century, it can even be used as a scientific approach in anti-corruption education [2] which has a more transformative impact than legal, political and psychological approaches [17], [18]. The religion education curriculum matrix redesign is an instrument for forming courses through the relationship between learning outcomes, study material, and mathematical formulas for calculating semester credit unit weights. It also provides a flexible space for the entry of new study materials in response to the latest scientific developments and policies, such as neuroscience and anti-corruption education.

\section{Method}

This study was conducted from 2016 until the beginning of 2019, using Research and Development [19]. This matrix was designed to respond to the latest scientific dynamics in their field (especially in neurosciences), synching with applicable national policies, specifically in implementing anticorruption education. This study involved 133 informants, including Islam, Catholic, and Hindu lecturers from various universities in Indonesia. The study consisted of three parts, namely, curriculum analysis, matrix design, and curriculum matrix testing. Curriculum analysis is carried out through focus group discussion with lecturers at the Catholic colleges in Medan, North Sumatra. The matrix design was carried out through a workshop forum at the Hindu College in Bali. Experimentation of matrix testing was carried out through a workshop forum in the higher education of the Islamic Religion, Kediri, East Java. Study Table 1. 
Table 1. Condition of research subjects

\begin{tabular}{|c|c|c|c|c|c|c|c|}
\hline \multirow{3}{*}{$\begin{array}{c}\begin{array}{c}\text { Condition of } \\
\text { research } \\
\text { subjects }\end{array} \\
\text { Gender }\end{array}$} & \multirow[t]{2}{*}{$\begin{array}{c}\text { Classification of } \\
\text { research } \\
\text { subjects }\end{array}$} & \multicolumn{2}{|c|}{$\begin{array}{l}\text { Analysis of } \\
\text { curriculum in } \\
\text { Medan, North } \\
\text { Sumatera (52 } \\
\text { informants) }\end{array}$} & \multicolumn{2}{|c|}{$\begin{array}{l}\text { Matrix design of } \\
\text { curriculum in } \\
\text { Bali (45 } \\
\text { informants) }\end{array}$} & \multicolumn{2}{|c|}{$\begin{array}{l}\text { The experiment of } \\
\text { curriculum matrix } \\
\text { in Kediri, East Java } \\
\text { (36 informants) }\end{array}$} \\
\hline & & 12 & $23.0 \%$ & 15 & $33.3 \%$ & 16 & $44.4 \%$ \\
\hline & Female & 40 & $77.0 \%$ & 30 & $66.7 \%$ & 20 & $55.5 \%$ \\
\hline \multirow{3}{*}{$\begin{array}{l}\text { Level of } \\
\text { education }\end{array}$} & Professor & 00 & $00.0 \%$ & 02 & $04.4 \%$ & 00 & $00.0 \%$ \\
\hline & Doctor & 02 & $03.8 \%$ & 05 & $11.2 \%$ & 06 & $16.6 \%$ \\
\hline & Magister & 50 & $96.2 \%$ & 38 & $84.4 \%$ & 30 & $83.4 \%$ \\
\hline \multirow{5}{*}{ Age } & $20-30$ & 10 & $19.2 \%$ & 10 & $22.2 \%$ & 15 & $42.6 \%$ \\
\hline & $31-40$ & 28 & $53.8 \%$ & 20 & $44.4 \%$ & 10 & $27.6 \%$ \\
\hline & $41-50$ & 09 & $17.3 \%$ & 12 & $26.7 \%$ & 06 & $16.6 \%$ \\
\hline & $51-60$ & 05 & $09.6 \%$ & 03 & $06.7 \%$ & 05 & $13.8 \%$ \\
\hline & $0-10$ years & 33 & $63.4 \%$ & 20 & $44.4 \%$ & 15 & $41.7 \%$ \\
\hline \multirow{3}{*}{$\begin{array}{l}\text { Experience of } \\
\quad \text { teaching }\end{array}$} & $10-20$ years & 11 & $21.1 \%$ & 15 & $33.3 \%$ & 10 & $27.7 \%$ \\
\hline & $20-30$ & 08 & $15.5 \%$ & 07 & $15.6 \%$ & 08 & $22.2 \%$ \\
\hline & More than 30 years & 00 & $00.0 \%$ & 03 & $06.7 \%$ & 03 & $08.4 \%$ \\
\hline
\end{tabular}

\section{Results and Discussion}

\subsection{Analysis of Curriculum}

Curriculum analysis was conducted at Catholic religion colleges throughout Indonesia gathered in Medan, North Sumatra, in August 2016, as shown in fig 1. The study indicates that the Catholic religious higher education curriculum is not referenced to the IQF, as shown in the mechanism used to form courses and calculate semester credit unit weight. They applied only a list of courses with semester credit unit weight which averages two credits per unit. Similar conditions also occurred in other religious colleges, such as Islam, Christianity, and Hinduism. In general, religious institutions are relatively slow to respond to the latest policies or regulations, including IQF.
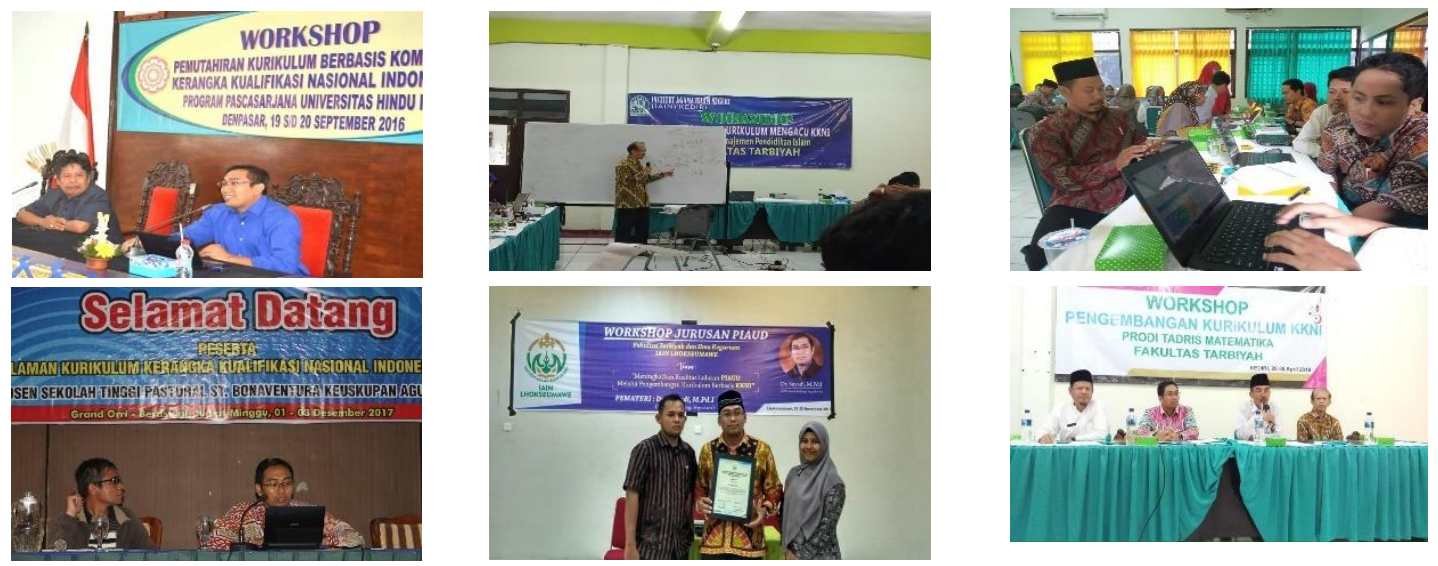

Fig. 1. Some photos of discussion activity of curriculum analysis in Medan, North Sumatera and focus group discussion describing the design of curriculum matrix in Bali, and experiment of curriculum matrix in Kediri, East Java

Furthermore, the examination of several syllabuses uncovered some overlap between study material in one subject and another because every lecturer oversees allied subjects that can be integrated. This condition has implications in superficial learning, including the range $\mathrm{C} 2$ in the taxonomy of bloom [20], whereas $21^{\text {st }}$ century learning ideally focuses more on Higher Order Thinking (HOT). Based on the analysis above, a curriculum matrix is needed to describe the study material for each subject for them to not overlap with others. Such a matrix can also be used as an instrument to accountably form courses and calculate the semester credit unit weight mathematically. 
Thus, there will be no course that appears suddenly without going through an academic mechanism that can be justified.

\subsection{Design matrix for the formation of courses and calculation of semester credit unit weights}

Based on the above analysis, starting in 2017, the religious higher education curriculum redesign was created, which linked learning outcomes with the study materials. Therefore, a mechanism for course formation and semester credit unit weight calculation can be obtained [21]. Achievement of the learning objective is prepared by a scientific consortium of each study program regarding IQF and the national standards of higher education. Furthermore, the formulation of learning outcomes is arranged vertically while the study materials were derived from the tree of the study program and arranged horizontally. The point where the formulation of learning outcomes and the corresponding study material meet forms a course. For learning achievement to measure the scope of sciences, its formulation contained four elements: depth (according to bloom's taxonomy of scale ranging one to six), IQF, standard national higher education, and width of study materials. Having fulfilled these four elements, credit weight could be calculated for the formed courses. The formula used was mathematical and automatic in the matrix. Thus, the matrix shown in Table 2 is an instrument for forming courses and calculating semester credit unit weights immediately, both mathematically and automatically.

Table 2. Matrix design of formation of courses and calculation of credit weight

\begin{tabular}{|c|c|c|c|c|c|c|c|c|c|c|c|c|}
\hline \multirow[b]{2}{*}{ IQF } & \multirow[b]{2}{*}{ SNDIKTI } & \multirow[b]{2}{*}{$\begin{array}{l}\text { Learning } \\
\text { Outcomes }\end{array}$} & \multicolumn{4}{|c|}{$\begin{array}{l}\text { Neuroscience } \\
\text { of Islamic } \\
\text { Education }\end{array}$} & \multirow[t]{2}{*}{ 류 } & \multirow[t]{2}{*}{ Courses } & \multirow[t]{2}{*}{$\sum^{2}$} & \multirow[t]{2}{*}{ 竞 } & \multirow[t]{2}{*}{ 胞 } & \multirow[t]{2}{*}{ : } \\
\hline & & & 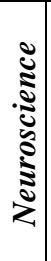 & 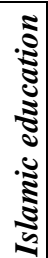 & 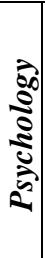 & 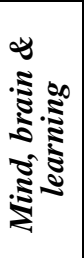 & & & & & & \\
\hline $\begin{array}{l}\text { "Able to apply } \\
\text { expertise and } \\
\text { use sciences, } \\
\text { technology, and } \\
\text { art to fields ..." }\end{array}$ & $\begin{array}{l}\text { "Able to apply } \\
\text { logic, critical } \\
\text { and creative } \\
\text { thinking to } \\
\text { sciences ...." }\end{array}$ & $\begin{array}{l}\text { Able to apply } \\
\text { logic, critical } \\
\text { and systematic } \\
\text { thinking to the } \\
\text { neuroscience } \\
\text { of Islamic } \\
\text { education. }\end{array}$ & $\sqrt{ }$ & $\sqrt{ }$ & $\sqrt{ }$ & $\sqrt{ }$ & & $\begin{array}{l}\text { Neuroscie } \\
\text { nce of } \\
\text { Islamic } \\
\text { Education }\end{array}$ & 4 & 3 & 12 & $\begin{array}{l}3,01 \\
(3 \\
\text { sks })\end{array}$ \\
\hline$\ldots$ & $\ldots$ & $\ldots$ & & & & & & $\ldots$ & $\ldots$ & $\ldots$ & $\ldots$ & $\ldots$ \\
\hline etc. & etc. & etc. & & & & & & & & & & \\
\hline & & & & & & & & & & & $\begin{array}{c}57 \\
4\end{array}$ & \\
\hline
\end{tabular}

Note:

$\mathrm{IQF}$

SNDIKTI

Learning Outcomes (LO)

Study materials

Courses

Width

Depth

Teaching materials

Credit weight**

$*)$
: Indonesia Qualification Framework

: Standard National Higher education

: Learning achievement that students must master

: Learnt scientific branch to ensure achievement of formulated LO.

: container of some mixed study materials that students and lecturers would explore in lecturing.

: Total branches of sciences that would be learned in a course.

: Cognitive measure of learning with the scale ranging from 1 to 6 according to bloom's taxonomy.

: Width $\mathrm{x}$ depth.

: Learning load: total learning load $\mathrm{x}$ minimum credits

Actual issues according to sciences importantly included in study materials

\subsection{Experimentation of matrix design}

Matrix design experiments were carried out in a workshop in early 2019 at the Kediri Islamic Religion Institute, East Java. The most recent policy regulation was presented, especially the IQF and 
Standard National Higher education, that must be referred to in the curriculum redesign of each study program. In formulating learning achievements, lecturers were guided to meet vital elements, such as depth and width of study materials and specific sciences. Furthermore, soft documents were distributed, which explained ways to use, as fig 1. The concept derived from IQF and SNDIKTI was demonstrated, and the lecturers could easily understand an average. However, while explaining the matrix of study materials, they became confused, partly because the study materials came from the scientific tree of the study programs, whereas, so far, no study programs are having academic documents containing the tree of sciences. They were further guided to make the tree of sciences, which can then be exposed to a matrix of horizontal study materials.

Furthermore, the formation of several courses by doing a checklist on the columns was illustrated (see Table1), which bring learning outcomes with the study material together. The semester credit unit weight for each subject can be calculated with the formula: breadth of the study material multiplied by the depth of learning achievement, further divided by the total learning load, and multiplied by the number of semester credit units a minimum $(\mathrm{S} 1=144)$. Table 1 , it is exemplified that the depth of learning achievement is three, the breadth of study material is four, and the total learning load is $\mathbf{5 7 4}$. This calculation will refer to Equation 1.

$$
\text { Neuroscience of Islamic Education }=\begin{array}{r}
4 \times 3 \\
574
\end{array} \quad \text { x } 144=3,01 \infty 3 \mathrm{sks}
$$

The equation will be more effective if the document is based on excel for the calculations to be carried out automatically. The disadvantage is that Excel documents are difficult to print out; hence, it is copied in Microsoft Word. Aside from the advantages and disadvantages of the matrix and its formulas, the matrix design is shown in Table 1 has answered the problem of curriculum redesign with accountable accounting mechanisms. The equation will be more effective if the document is based on excel so that the calculation of credit weight could be done automatically. Conversely, excel is difficult to print out as a curriculum document, hence, MS Word was used. Lecturers who were less familiar with excel software would experience more serious difficulty than informants frequently operating the software. Regardless of the strength and weakness of matrix and equation, Table 1 shows Medan, North Sumatera had responded to the problems of courses so far without an accountable mechanism.

Logically, the consequence of curriculum redesign referring to IQF and standardization of national higher education involves reducing courses and further increasing the credit weight of each. This was caused by previous curriculum analysis, in which almost all study programs had too many courses with low credit weight, and their reduction automatically increased credit weight. Another consequence of this modification is the emergence of new classes, which are merely a combination of several similar subjects whose syllabus overlaps. However, new courses can also emerge because they respond to the progress of science in their fields and synchronize with other applicable regulations. These circumstances caused turmoil among the internal lecturers of the study program because they would lose some courses they managed for years. Conversely, the formation of new courses often requires the impact of new lecturers according to their expertise.

Pasiak recommended that neurosciences should be included in the curriculum of religious higher education, especially in Islamic education [22], because new findings, especially in neuro-theology [23], [24], have contributed significantly to religion studies scientifically, which no longer occurs dogmatically. This recommendation is relevant to the era of disruption, stating that Islam study should use inter, multi, and transdisciplinary approaches when integrating sciences [25], [11], [26]. Specifically, neuroscience suggests that teachers are professionals whose job changes brain every day [18]. However, through the centuries, they did not understand this concept [27]. Therefore, an appropriate response to the development of the most recent sciences in curriculum redesign is to enter neurosciences into the matrix of study materials.

In terms of synchronizing with the policies enforced in Indonesia, the curriculum redesign must also refer to Law No. 30 article 13c, which states that the Corruption Eradication Commission is tasked with providing anti-corruption education in all educational institutions, including Islamic higher education. This should be carried out because Indonesia is still ranked as the fourth most corrupt country globally, in line with Suyadi's research on the model of the integration of anti-corruption education in Islamic education [27]. Furthermore, several universities have formed anti-corruption 
courses as compulsory subjects in all study programs. The design of the curriculum matrix should therefore be flexible towards the entry of new study materials.

\section{Conclusion}

Based on the results and discussion, it can be concluded that the curriculum matrix design developed can be applied in all study programs in religious higher education, including Islamic, Catholic, and Hindu education. It has further integrated learning outcomes and study material, used as an instrument for course formation and accountable and mathematical calculation of SSE credit unit weight. This matrix design also provides a flexible space for educational programs to include new study material in response to the development of science in their fields, especially in neuroscience, and synchronize other applicable national policies in Indonesia, especially in anti-corruption education.

\section{Acknowledgment}

The authors would like to thank colleagues from Institut Agama Islam Negeri Kediri, Sekolah Tinggi Agama Islam Ibnu Sina Batam, STAILE Pekanbaru, Universitas Hindu Bali, Sekolah Tinggi Pastoral ST. Bonaventura Keuskupan Agung Medan, Sekolah Tinggi Kateketik Pastoral Toraja, Institut Agama Islam Negeri Palu, Universitas Islam Negeri Imam Bonjol Padang, and Institut Agama Islam Negeri Lhokseumawe Aceh for helping with this research. Also thank to the Faculty of Islamic Studies, Universitas Ahmad Dahlan for the granted supports.

\section{Declarations}

Author contribution $\quad$ : SY: Writing original draft preparation. ST: Conceptualization and methodology. ZN: Writing, reviewing, editing, and visualization.

Funding statement $\quad:$ No funding was made available for this research.

Conflict of interest $\quad$ : The authors declare no conflict of interest.

Additional information : No additional information is available for this paper.

\section{References}

[1] Sutrisno dan Suyadi, Desain Kurikulum Pendidikan Tinggi Mengacu KKNI. Bandung: Rosda Karya, 2015, available at: Google Scholar.

[2] Suyadi, "Mainstreaming the Knowledge of Islamic Education With Progress and of Islam Nusantara Education," Akademika, vol. 24, no. 1, pp. 37-66, 2019, doi: 10.32332/akademika.v24i1.1613.

[3] Suyadi, Teori Pembelajaran Anak usia Dini Dalam Kajian Neurosains. Bandung: Rosda Karya, 2016, available at: Google Scholar.

[4] S. Suyadi, S. Sumaryati, D. Hastuti, D. Yusmaliana, and R. D. Rahmah MZ, "Constitutional Piety: The Integration of Anti-Corruption Education into Islamic Religious Learning Based on Neuroscience," $J$ PAI J. Pendidik. Agama Islam, 2019, doi: 10.18860/jpai.v6i1.8307.

[5] K. A. Seaton, "Curriculum Redesign to Provide Opportunities for a Diversity of Students," Int. J. Innov. Sci. Math. Educ., vol. 23, no. 1, pp. 74-81, 2015, available at: Google Scholar.

[6] M. A. Khan and L. S. Law, "An Integrative Approach to Curriculum Development in Higher Education in the USA: A Theoretical Framework," Int. Educ. Stud., vol. 8, no. 3, pp. 66-76, 2015, doi: 10.5539/ies.v8n3p66.

[7] D. G. Brauer and K. J. Ferguson, "The Integrated Curriculum In Medical Education: AMEE Guide No. 96," Med. Teach., vol. 1, no. 96, pp. 312-322, 2015, doi: 10.3109/0142159X.2014.970998.

[8] H. Chung and J. Kim, "An Ontological Approach for Semantic Modeling of Curriculum and Syllabus in Higher Education,” Int. J. Inf. Educ. Technol., vol. 6, no. 5, pp. 365-369, 2016, doi: 10.7763/IJIET.2016.V6.715.

[9] E. Purwaningsih and D. Nurhadi, "Innovative Lesson Study (LS) to Improve the Pedagogical Content Knowledge (PCK) of STEM Teacher Candidates in Indonesia," Glob. J. Eng. Educ., vol. 20, no. 1, pp. 
39-47, 2018, available at: Google Scholar.

[10] Suyadi, "Millennialization of Islamic Education Based on Neuroscience in the Third Generation University in Yogyakarta Indonesia," QIJIS Qudus Int. J. Islam. Stud., vol. 7, no. 1, pp. 173-202, 2019, doi: 10.21043/qijis.v7i1.4922.

[11] S. Suyadi, "A Genealogycal Study of Islamic Education Science at The Faculty of Ilmu Tarbiyah dan Keguruan UIN Sunan Kalijaga,” Al-Jami'ah J. Islam. Stud., vol. 56, no. 1, pp. 29-58, 2018, doi: 10.14421/ajis.2018.561.29-58.

[12] Suyadi, "Integration of Anti-Corruption Education (PAK) In Islamic Religious Education (PAI) With Neuroscience Approach (Multi-Case Study in Brain Friendly PAUD: I Sleman Kindergarten Yogyakarta)," Inferensi, J. Penelit. Sos. Keagamaan, vol. 12, no. 2, pp. 307-330, 2018, doi: 10.18326/infs13.v12i2.307-330.

[13] P. R. Indonesia, Undang -Undang Republik Indonesia Nomor 30 Tahun 2002 Tentang Komisi Pemberantasan Tindak Pidana Korupsi. Jakarta: Presiden Republik Indonesia, 2002, available at: Google Scholar.

[14] T. Ikrar, Ilmu Neurosains Modern. Yogyakarta: Pustaka Pelajar, 2016, available at: Google Scholar.

[15] Suyadi, "Hybridization of Islamic Education and Neuroscience: Transdisciplinary Studies of 'Aql in the Quran and the Brain in Neuroscience," Din. Ilmu, vol. 19, no. 2, pp. 1-20, 2019, doi: 10.21093/di.v19i2.1601.

[16] R. D. R. M. Suyadi, Sumaryati, Dwi Hastuti, Desfa Yusmaliana, "Constitutional Piety: The Integration of Anti-Corruption Education into Islamic Religious Learning Based on Neuroscience," J-PAI J. Pendidik. Agama Islam, vol. 6, no. 1, pp. 38-46, 2019, doi: 10.18860/jpai.v6i1.8307.

[17] T. Gong, S. Wang, and J. Ren, "Corruption in the Eye of the Beholder: Survey Evidence from Mainland China and Hong Kong," Int. Public Manag. J., vol. 18, no. 3, pp. 458-482, 2015, doi: 10.1080/10967494.2015.1057629.

[18] J. Greene and J. Cohen, "For the law, neuroscience changes nothing and everything," in The Royal Society, 2004, no. November, pp. 1775-1785, doi: 10.1098/rstb.2004.1546.

[19] M. D. Gall, W. R. Borg, and J. P. Gall, Educational research: An introduction. Longman Publishing, 1996, available at: Google Scholar.

[20] F. A. Adesoji, "Bloom Taxonomy Of Educational Objectives And The Modification Of Cognitive Levels," Adv. Soc. Sci. Res. J., vol. 5, no. 5, pp. 292-297, 2018, doi: 10.14738/assrj.55.4233.

[21] Tim Penyusun, Kurikulum Pendidikan Tinggi Mengacu KKNI dan SN-DIKTI Program Studi Magister Pendidikan Agama Islam Universitas Ahmad Dahlan Yogyakarta. Yogyakarta: UAD Press, 2017.

[22] T. Pasiak, "Tuhan Dalam Otak Manusia : Mewujudkan Kesehatan Spiritual Berdasarkan Neurosains," Mizan, Bandung, 2016, available at: Google Scholar.

[23] Andrew Newberg \& Mark Robert Waldman, How God Changes Your Brain, Breakthrough Findings From a Learning Neuroscientist. New York: Ballantine Books, 2009, available at: Google Scholar.

[24] A. Sayadmansour, "Neurotheology: The Relationship Between Brain and Religion," Iran. J. Neurol., vol. 13, no. 1, pp. 52-55, 2014, available at: Google Scholar.

[25] M. A. Abdullah, "Religion, Science, and Culture: An Integrated, Interconnected Paradigm of Science," Al-Jami'ah J. Islam. Stud., vol. 52, no. 1, p. 175, 2015, doi: 10.14421/ajis.2014.521.175-203.

[26] Suyadi, "Diferensiasi Otak Laki-laki dan Perempuan Guru Taman Kanak-kanak Aisyiyah Nyai Ahmad Dahlan Yogyakarta: Studi Pendidikan Islam Anak Usia Dini Perspektif Gender dan Neurosains," Sawwa J. Stud. Gend., vol. 13, no. 2, pp. 179-202, 2018, doi: 10.21580/sa.v13i2.2927.

[27] Robert Sylwester, Memahami Perkembangan \& Cara Kerja Otak Anak-anak. Jakarta: Indeks, 2012, available at: Google Scholar. 